\title{
TECHNICAL INEFFICIENCY AND ITS DETERMINANTS IN FOOD CROPS PRODUCTION IN IMO STATE, NIGERIA
}

\section{OHAJIANYA D.O, P.C. OBASI AND J.S. OREBIYI}

\begin{abstract}
Technical inefficiency among food crops farmers in Imo State was estimated using stochastic translog production frontier. The mean output of food crops farmers was 20.3 tons/ha, which is 9.6 tons/ha less than the expected food crops output of 30 tons/ha, and the mean level of technical inefficiency was 61.5 percent with a wide range from $21.24-98.13$ percent. Major determinants of technical inefficiency were education, household size, farm size, access to credit, extension contact, farming experience and family labour use. There are still opportunities for increasing technical efficiency, productivity and farm income in food crops production in Imo state if these factors and given the desired attention.
\end{abstract}

Keywords: Stochastic translog, technical inefficiency, food crops, farmers, Imo State.

\section{INTRODUCTION}

Agricultural production in Imo State is dominated by food crops farmers. Yam, cassava, rice and maize are the major food crops extensively cultivated by the farmers. Despite the large expanse of farm land devoted to food crops production, the huge amount of resources of labour, capital and management invested, outputs still remain low (19 tons/ha (Ewulonu 2002))to meet the increasing food demand which is growing at about $4.5 \%$ per annum (FAO, 1989). This decline in output is traceable to inefficient use of resource inputs (Onyenweaku 1986, Ohajianya and Onyenweaku 2001 and 2002, Olagoke 1991, Onyenweaku and Nwaru 2005, Onyenweaku and Fabiyi 1991, Onyenweaku, Agu and Obasi 2000, Ohajianya 2006, Awoke 2004). However, none of these studies provided numerical measures of technical inefficiency, thereby leaving a gap in knowledge which this study is designed to fill. The objective of this study is to measure technical inefficiency and its determinants in food crops production in Imo State of Nigeria, using the stochastic translog frontier model. Farm efficiency, and the question of low to measure it, is an important subject in developing countries agriculture. There are three distinct approaches to measurement based on cost, profits and production functions. Farrell (1957) developed the concept of technical efficiency based on input and output relationships. Technical inefficiency arises when actual or observed output from a given input mix is less than the maximum possible; while allocative inefficiency arises when the input mix is not consistent with cost minimization (Parikh, Ali and Shah, 1995) .

A stochastic translog production frontier is defined by:

$Y_{i}=f\left(X_{i}, Z_{i}, D_{i}\right) \operatorname{exp~e} e_{i}, i=1,2$

Where; $Y_{i}$ is output of the ith farmer, $X_{i}$ is the vector of variable input quantities used by the $i^{\text {th }}$ farmer, $Z_{i}$ is the quantities of fixed inputs used by the $i^{\text {th }}$ farmer, $D_{i}$ is the dummy variable for soil conditions of the $\mathrm{i}^{\text {th }}$ farmer, $\mathrm{f}($.) represents an appropriate function (eg, translog, Cobb Douglas).

$\mathrm{e}_{\mathrm{i}}=\mathrm{V}_{\mathrm{i}}-\mathrm{U}_{\mathrm{i}}$

The term $V_{i}$ is a symmetric error, which accounts for random variations in output due to factors beyond the control of the farmer e.g. weather, disease outbreaks, measurement errors, etc, while the term $U_{i}$ is a non-negative random variable representing inefficiency in production relative to the stochastic frontier. The random error $V_{i}$ is assumed to be independently and identically distributed as $\mathrm{N}\left(0, \sigma_{\mathrm{V}}{ }^{2}\right)$ random variables independent of the $\mathrm{U}_{\mathrm{i}}$ which are assumed to be non-negative truncations of the $\mathrm{N}\left(0, \sigma_{\mathrm{u}}{ }^{2}\right)$ distribution (ie, half 
normal distribution) or have exponential distribution. Thus, $\mathrm{U}_{\mathrm{i}}>0$ is a one sided error term representing production inefficiency; $U_{i}$ measures production inefficiency in that it measures shortfall in farm output $\left(\mathrm{Y}_{\mathrm{i}}\right)$ from its maximum possible value. Thus, if $\mathrm{U}_{\mathrm{i}}=0$, the farm lies on the production frontier, obtaining maximum output given the levels of resource inputs. If $\mathrm{U}_{\mathrm{i}}>0$, the farm is inefficient and experiences shortfall in output due to inefficiency (Forsund et al 1980, Fare and Lovell 1985, Jondrow et al 1982).

The farm average technical inefficiency is specified as;

$\mathrm{E}\left(\mathrm{e}^{-\mathrm{U}}\right)=2 \mathrm{e}^{\sigma \mathrm{v} 2}\left(\mathrm{I}-\mathrm{F}\left(\sigma_{\mathrm{u}}\right)\right)$

Where, $\mathrm{F}$ is the standard normal distribution function.

Measurement of farm level inefficiency, $\mathrm{e}^{\mathrm{u}}$, requires first the estimation of the non-negative error, $\mathrm{U}$, ie, decomposition of the $\mathrm{e}_{i}$ into its two individual components, $\mathrm{U}$ and v. Jondrow et al (1982) suggest a technique for this decomposition using the conditional distribution of $U$ given e. The conditional mean of $U$ given e is shown to be

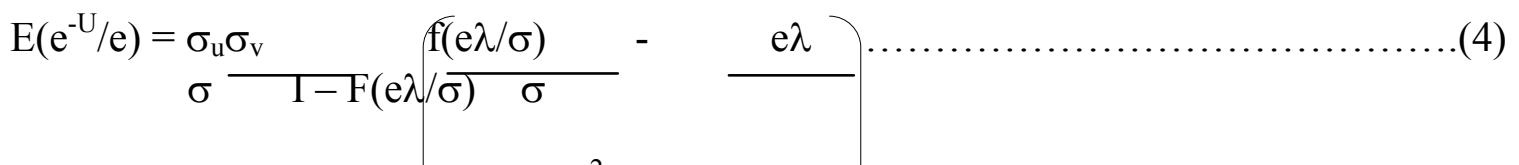

Where, $\left(=\left(\mathrm{u} /\left(\mathrm{v}\right.\right.\right.$ and $\left(2=\left(\mathrm{u} 2+\left(\mathrm{v}_{\mathrm{v}}^{2}\right.\right.\right.$, and $\mathrm{f}$ and $\mathrm{F}$ are the standard normal density function and the standard normal distribution function respectively. For e, ( and (, the estimated values are used to evaluate the density (f) and the distribution (F) function.

\section{METHODOLOGY}

This study was conducted in Imo State of Nigeria. It lies within latitudes $5^{\circ} 40^{\prime}$ and $7^{0}$ $05^{\prime}$ North and longitudes $5^{0} 35^{\prime}$ and $8^{0} 30^{\prime}$ East. It had a population of about 2, 485, 499 people in 1991 (NPC, 1991). The state is divided into three agricultural zones, namely; Owerri, Orlu and Okigwe, and further divided into 27 Local Government Areas (LGAs). Farming is the major occupation of the people. The weather and soil conditions of Imo State favours the production of food crops such as yam, cassava, rice and maize. A multistage sampling technique was used to select respondents. The state was stratified into the existing three agricultural zones. Through a reconnaissance survey of the state, two major food crops producing LGAs were purposively selected from each agricultural zone, giving a total of six LGAs. Two communities were purposively selected from each selected LGA based on dominance of food crops farmers, making a total of 12 communities. The sampling frame was the lists food crops farmers in the selected communities, compiled with the assistance of resident agricultural extension agents and key informants. From these lists totaling 159 farmers for the 12 communities, five farmers were randomly selected from each community, making a sample size of 60 food crops farmers for the study. Data were collected with structured and validated questionnaire on the socio-economic characteristics of the farmers and production activities in terms of variable and fixed inputs, soil conditions, outputs and their prices using the cost-route approach from March to November 2005.

\section{Analytical techniques:}

Measurement of technical inefficiency of food crops farmers. Stochastic translog production frontier was used for the measurement of technical inefficiency in food crops production in Imo State. The implicit form of this model is;

$Y_{i}=f\left(X_{1 i}, X_{2 i}, X_{3 i}, Z_{1 i}, Z_{2 i}, D_{i}\right) \operatorname{exp~} e_{i}, \quad i=1,2$

Where,

$\mathrm{Y}_{\mathrm{i}}=$ food crops output per farmer ( $)$

$\mathrm{X}_{1 \mathrm{i}}=$ labour input per farmer (mandays)

$\mathrm{X}_{2 \mathrm{i}}=$ planting materials used per farmer $(\#)$ 
$\mathrm{X}_{3 \mathrm{i}}=$ quantity of fertilizer used per farmer (N0. of $50 \mathrm{~kg}$ bags)

$\mathrm{Z}_{1 \mathrm{i}}=$ land input per farmer $(\mathrm{Ha})$

$\mathrm{Z}_{2 \mathrm{i}}=$ Depreciation on capital inputs per farmer (

$\mathrm{D}_{\mathrm{i}}=$ dummy variable for soil conditions per farmer

$(\mathrm{D}=1$ for good soils and zero for problem saline soils )

$\mathrm{ei}=\mathrm{V}_{\mathrm{i}}-\mathrm{U}_{\mathrm{i}}$

Where, $V_{i}$ and $U_{i}$ are as defined in equation 2 .

Technical inefficiency per farmer TIE $=\mathrm{E}\left(\mathrm{e}^{-\mathrm{u}}\right)=2 \mathrm{e}^{(\mathrm{v} 2}\left(1-\mathrm{F}\left(\mathrm{(u}_{\mathrm{u}}\right)\right)$

Where $\mathrm{e}_{\mathrm{i}}\left({ }_{\mathrm{v}}{ }^{2}\right.$ and $(\mathrm{u}$ are as defined earlier.

\section{Determinants of technical Inefficiency.}

In order to determine the factors contributing to the observed technical inefficiency, the following model was formulated and estimated jointly with the stochastic translog production frontier in a single stage maximum likelihood estimation (MLE) procedure using the computer software LIMDEP version 7.0

$\mathrm{TIE}=\mathrm{a}_{\mathrm{o}}+\mathrm{a}_{1} \mathrm{~K}_{1}+\mathrm{a}_{2} \mathrm{~K}_{2}+\mathrm{a}_{3} \mathrm{~K}_{3}+\mathrm{a}_{4} \mathrm{~K}_{4}+\mathrm{a}_{5} \mathrm{~K}_{5}+\mathrm{a}_{6} \mathrm{~K}_{6}+\mathrm{a}_{7} \mathrm{~K}_{7}+\mathrm{a}_{8} \mathrm{~K}_{8}+\mathrm{a}_{9} \mathrm{~K}_{9}+\mathrm{a}_{10} \mathrm{~K}_{10}+$ $\mathrm{a}_{11} \mathrm{~K}_{11} \ldots \ldots \ldots \ldots \ldots \ldots \ldots \ldots(8)$

Where, $\mathrm{TIE}_{\mathrm{i}}=$ technical inefficiency of the $\mathrm{i}^{\text {th }}$ farmer, $\mathrm{K}_{1}$ is farmer's level of education in years, $K_{2}$ is farmer's household size measured in number of people, $K_{3}$ is membership of farmers associations/cooperative societies (dummy variable, 1 for member, zero otherwise), $\mathrm{K}_{4}$ is farm size in hectares, $\mathrm{K}_{5}$ is credit access (dummy variable, 1 if the farmer has access to credit, zero otherwise), $\mathrm{K}_{6}$ is extension contact (number of visits), $\mathrm{K}_{7}$ is access to agrochemicals (dummy variable, 1 if the farmer has access to agrochemical, zero otherwise), $\mathrm{k}_{8}$ is farmer's age in years, $k_{9}$ is farmer's farming experience in years, $K_{10}$ is gender of the farmer (dummy variable, 1 for male, zero for female). $\mathrm{K}_{11}$ is family labour use (mandays). The coefficients of education, farm size credit, extension, farming experience, family labour use and gender are expected to be negative, and those for the other variables are expected to be positive.

\section{RESULTS AND DISCUSSION}

Average statistics of food crops farmers.

Table 1 shows that, on the average, a food crop farmer is 51.6 years old, with household size of 11 people, 27.4 years of farming experience and 7.5 years of education.

Table 1. Average statistics of food crops farmers.

\section{Variable}

Age

Households size

Farming experience

Education

Farm size

Capital

Planting materials

Labour

Fertilizer

Output

Source: survey data, 2005

The average food crop farmer cultivated 2.7 hectares of land, spent $\$ 1945.63$ on capital inputs, $11,539.27$ on planting materials, employed 95.3 mandays of labour, applied 4.5 bags of fertilizer and produced an output of N90, 513.39.
Average value
51.62 years
10.93 people
27.43 years
7.54 years
2.67 hectares
$\$ 1945.63$
$\$ 11,539.27$
95.27 man-days
4.49 bags
$\$ 90,513.39$ 


\section{Estimated translog Production Frontier.}

The Maximum Likelihood Estimates (MLE) of equation 5 and 8 on a per farmer basis are presented in table 2 . The variance parameter, $\lambda=\quad\left(\left(\mathrm{u}^{2} /(\mathrm{v})\right.\right.$ is statistically greater than zero and large (0.89), implying that variation in actual farm output from maximum output between farms mainly arose from differences in farmer practices rather than random variability. The coefficients $f$ the estimated parameters for the variables; labour, planting materials, fertilizer, land and capital have the desired positive signs, and are statistically significant at 0.01 level. The implication of this is that if the levels used of these inputs in Imo state are increased beyond their present levels, they will significantly reduce technical inefficiency in food crops production.

Table 2. Estimated Translog production Frontier for food crops farmers in Imo State.

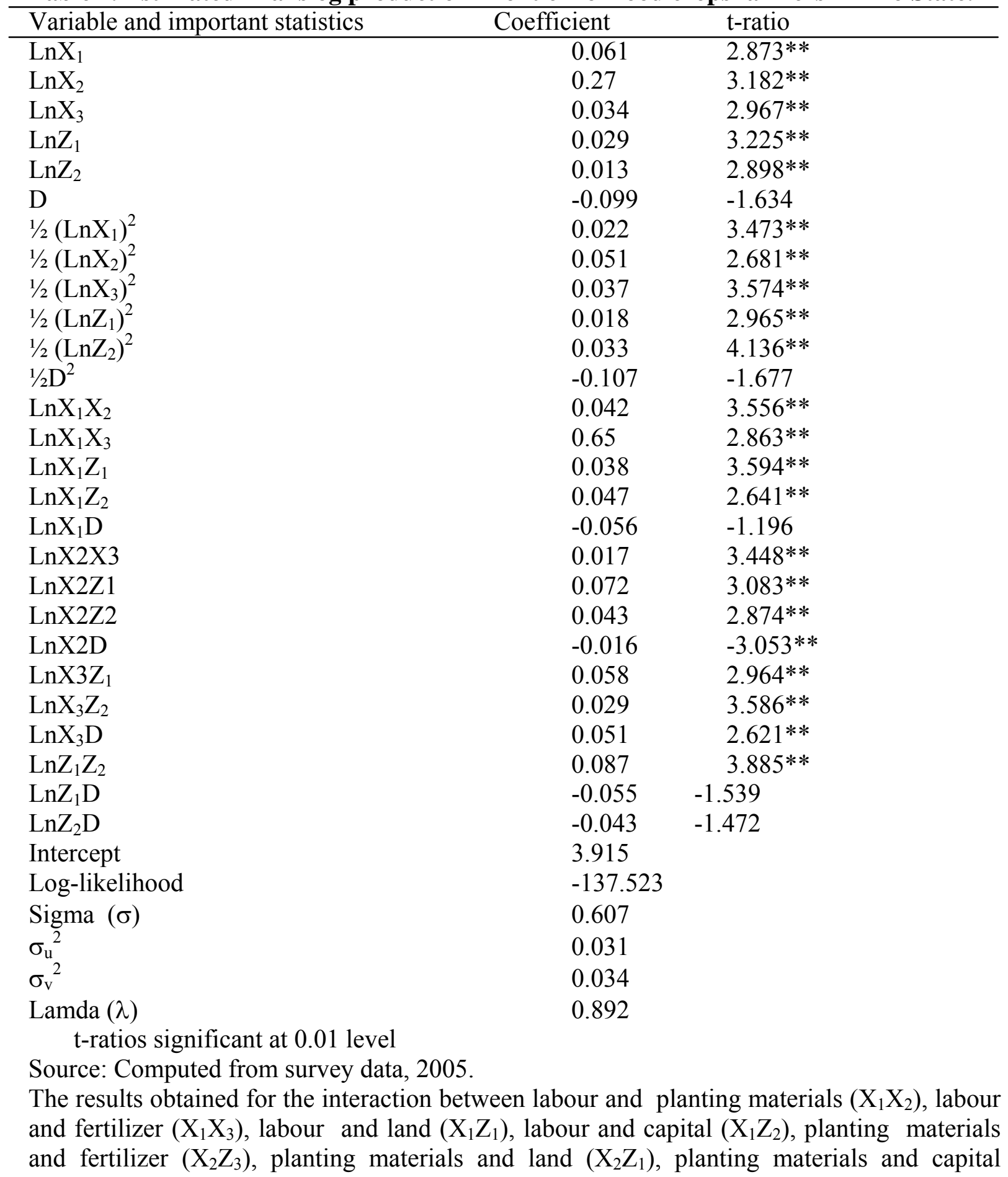


$\left(\mathrm{X}_{2} \mathrm{Z}_{2}\right)$, fertilizer and land $\left(\mathrm{X}_{3} \mathrm{Z}_{2}\right)$, and land and capital $\left(\mathrm{Z}_{1} \mathrm{Z}_{2}\right)$ show that there is significant positive interaction between these inputs, suggesting that increases in the level of these inputs used in food crops production would reduce the level of inefficiency observed presently.

The result obtained for the interaction between planting materials and soil condition shows that there is a significant negative interaction between these variables, implying that if the soil condition is poor, the use of improved planting materials on such soils would lead to higher technical inefficiency. The result for the interaction between fertilizer application and soil condition shows that there is a significant positive interaction between these variables, indicating that if fertilizer is added to poor soil, the fertilizer improves the soil condition and hence reduces technical inefficiency.

Table 3 shows that most (40\%) of the food crops farmers produced an output range of 21-23 tons/ha with a mean of 20.3 tons/ha, which differed from the expected food crops output of 30 tons/ha by 9.6 tons/ha, indicating technical inefficiency since there was a loss in output.

Table 3. Distribution of food crops farmers according to their outputs

Food crops output Frequency Relative Frequency

(tons/ha)

\begin{tabular}{lcc}
$\leq 14$ & 5 & 8.3 \\
$15-17$ & 8 & 13.3 \\
$18-20$ & 15 & 25.0 \\
$21-23$ & 24 & 40.0 \\
$24-26$ & 6 & 10.0 \\
27 and above & 2 & 3.4 \\
\hline Total & $\mathbf{6 0}$ & $\mathbf{1 0 0}$ \\
Mean out put & 20.3 tons/ha & \\
Expected out & 30 tons/ha (Phillips 1977) \\
Output loss & 9.6 tons/ha & \\
\hline
\end{tabular}

Source: Survey data, 2005

Table 4 shows that the technical inefficiency of food crops farmer range between 21.24 percent and 98.13 percent with a mean of 61.5 percent. About 76.7 percent of the food crops farmers had a technical inefficiency index of above 50 percent.

The mean technical inefficiency of 61.5 percent implies high level technical inefficiency in resource use and suggests that there are still opportunities for increasing productivity and farm income through reduction in technical inefficiency in resource use by food groups farmers in Imo State. 
Journal Of Agriculture and Social Research (JASR) Vol. 6, No.2, 2006

Table 4 Frequency Distribution of technical inefficiency in food crops production in Imo State.

Technical Inefficiency $\quad$ Frequency Relative Frequency

\begin{tabular}{lll} 
Range $(\%)$ & & \\
\hline $21-\quad 30$ & 2 & 3.33 \\
$31-\quad 40$ & 7 & 11.67 \\
$41-50$ & 5 & 8.33 \\
$51-60$ & 10 & 16.67 \\
$61-70$ & 21 & 35.00 \\
$71-80$ & 8 & 13.33 \\
$81-90$ & 4 & 6.66 \\
$91-100$ & 3 & 5.01 \\
Total & $\mathbf{6 0}$ & $\mathbf{1 0 0 . 0 0}$ \\
Mean technical inefficiency 61.5\% & \\
Minimum technical inefficiency 21.24\% & \\
Maximum technical inefficiency $98.13 \%$ &
\end{tabular}

Source: Survey data, 2005

\section{Determinants of Technical inefficiency:}

The determinants of technical inefficiency in food crops production in Imo State are presented in table 5. The result shows that food crops farmers with more education, larger farm size, more access to credit, higher number of extension visits, more farming experience and uses more family labour are significantly less technical inefficient in food crops production. Also food crops farmers that are very old and those that have many people in their households are significantly more technical inefficient in food crops production. These findings are consistent with those of Ali and Flinn (1989) , Lockheed et al (1999), and Ohajianya (2005).

Table 5:Estimated Determinants of Technical Inefficiency in Food Crops Production in Imo State

$\begin{array}{lll}\text { Variable } & \text { Parameter } & \text { Estimate } \\ \text { Constant } & \mathrm{a}_{\mathrm{p}} & 4.103 \\ & & (3.818)^{* *} \\ \text { Education }\left(\mathrm{K}_{1}\right) & \mathrm{a}_{1} & -0.408 \\ & & (-3.913)^{* *} \\ \text { Household size }\left(\mathrm{K}_{2}\right) & \mathrm{a}_{2} & -0.031 \\ & & (-2.333)^{*} \\ \text { Membership of farmers associations }\left(\mathrm{K}_{3}\right) & \mathrm{a}_{3} & 0.061 \\ & & (1.133) \\ \text { Farm size }\left(\mathrm{K}_{4}\right) & \mathrm{a}_{4} & -0.029 \\ & & (-3.802)^{* *} \\ \text { Credit }\left(\mathrm{K}_{5}\right) & \mathrm{a}_{5} & -0.073 \\ & & (-3.138)^{* *} \\ \text { Extension Contact }\left(\mathrm{K}_{6}\right) & \mathrm{a}_{6} & -0.022 \\ & & (-2.514)^{*} \\ \text { Agro-chemicals }\left(\mathrm{K}_{7}\right) & \mathrm{a}_{7} & 1.203 \\ & & (1.347) \\ \text { Age }\left(\mathrm{K}_{8}\right) & \mathrm{a}_{8} & 0.218 \\ & & (2.203)^{*}\end{array}$


Journal Of Agriculture and Social Research (JASR) Vol. 6, No.2, 2006

$\begin{array}{lcc}\text { Farming Experience }\left(\mathrm{K}_{9}\right) & \mathrm{a}_{9} & -0.167 \\ \text { Gender }\left(\mathrm{K}_{10}\right) & & (-2.964)^{* *} \\ \text { Family labour use }\left(\mathrm{K}_{11}\right) & \mathrm{a}_{10} & -0.015 \\ & \mathrm{a}_{11} & (-1.403) \\ & & -0.139 \\ & & (-3.116)^{* *}\end{array}$

Figures in parentheses are t-ratios.

$* \mathrm{t}$ - ratios significant at 0.05 level

** t-ratios significant at 0.01 level

Source: survey data, 2005.

\section{CONCLUSION AND POLICY IMPLICATIONS}

The findings of this study reveal that the level of technical inefficiency in food crops production in Imo State, Nigeria ranges between 21.24 percent to 98.13 percent with a mean of 61.5 percent, suggesting that there are still opportunities for increasing productivity and farm income in Imo State through reduction in technical inefficiency in resource use. Major factors inversely related to technical inefficiency are education, farm size, access to credit, extension contact, farming experience family and labour use, while household size and age were found to be directly related to technical inefficiency.

To reduce technical inefficiency in food crops production there is need for policies aimed at; reducing farmers' non access to credit by relaxation of insistence on provision of tangible collaterals by lending institutions in Imo State; encouraging the farmers to attain formal education through adult education ad evening classes programmes; increasing the number of extension visits to the farmers by motivating the field extension workers; and enlightening the farmers to use more family labour which is a cheaper source of labour in their food crops production activities. Also policies aimed at encouraging farmers to reduce their household sizes and acquire more relevant experience in farming before planting certain food crops in their farms will be fundamental to reducing the level of technical inefficiency in Imo State.

\section{REFERENCES}

Ali M. and Flinn, C (1989). Profit efficiency among Basmati Rice Producers in Pakistain Punjab. American Journal of Agricultural Economics, PP. 304 - 310.

Awoke, M.U (2004). Resource use Efficiency in Multiple Cropping Systems by Smallholder Farmers in Ebonyi state Nigeria.

FAO (1889). "Utilization of Tropical Food" Annual Report Abstract FAO, Rome.

Fare R and C.K. Lovell (1985). The measurement of Efficiency of production, Boston Kilujwer Nijoff.

Farrell, J.M (1957) The measurement of production efficiency. Journal of Royal Statistics Society (series A) 120 (3): $253-290$.

Forsund F.C. K. Lovell and P. Schmidt (1980). "A survey of frontier production functions and their relationship to efficiency measurement " Journal of Econometrics, 13 (1): 525.

Jondrow, J.C, A Knox Lovell, I.S Materou, and P. Scmidt (1982), "On the Estimation of Technical Inefficiency in the stochastic Frontier Production Function Model" Journal of econometrics, 19(1): $233-238$.

Lockheed M.E; Jamison D.T, and lau L.J (1999). "Farmer and Farm Efficiency; A survey. Economic Development and cultural change, 29(2): 37 - 76.

National Population Commission (1991). Census figure. 


\section{Journal Of Agriculture and Social Research (JASR) Vol. 6, No.2, 2006}

Ohajianya D.O. (2005) . Profit efficiency among Cocoyam producers in Imo State "stochastic translog profit frontier approach". Proceedings of the $39^{\text {th }}$ conference of the Agricultural society of Nigeria, Benin, Pp $332-335$.

Ohajianya D.O and C.E Onyenweaku (2001) "Gender and relative Efficiency in rice production systems in Ebonyi state of Nigeria Nigerian Journal of Agriculture and sustainable environment, 3(2): $394-392$.

Ohajianya D.O and C.E. Onyenweaku (2002). "Farm size and Relative Efficiency in Rice Production in Ebonyi state, Nigeria". Journal of Modelling, Simulation and control, 23(2):1-16.

Ohajianya D.O (2006) Resource use efficiency of land owners and tenants in food crops production in Imo State Nigeria. Journal of sustainable Agricultural research (Accepted).

Olagoke, M.A (1991). "Efficiency of Resource use in Rice production systems, in Anambra state, Nigeria”. Issues in African Rural Development, vol 1, Dos C.R and C. Son (ed). Winrock International, Pp . 319 - 342.

Onyenweaku C.E; S.E Agu and P.C Obasi (2000). Economics of small holder rice farming under various production systems in South Eastern Nigeria". Nigeria Journal of agricultural Business and Rural Development, 1(1): 1-11.

Onyenweaku C.E. and Y.L Fabiyi (1991) Relative Efficiency of Co-operatives and individual farmers in food production in Imo State, Nigeria' AMSE Transactions, 8(4): 23-32.

Onyenweaku C.E. and J.C Nwaru (2005). Application of a stochastic frontier production function to the measurement of technical efficiency in food crop production $\mathrm{n}$ Imo State, Nigeria. The Nigerian Agricultural Journal, 36(1): 1-12.

Onyenweaku C.E. (1986). Resource use efficiency in food production in Nigeria. A case study of Anambra-Imo River Basin Development Authority. Issues in African Rural Development Monograph series,N0.6.

Parikh A, Ali F and M.K Shah (1995). "Measurement of Economic Efficiency in Pakistan Agriculture". American Journal of Agricultural Economics, PP. 675 - 685.

Philips T.A (1977). “An Agricultural Notebook”. Longman Group Ltd London. Pp. 6-88. 